\title{
A belvízi veszélyesáru-szállítás hatósági felügyeletével kapcsolatos tapasztalatok értékelése a bírságjogszabály változásának következtében
}

\author{
Evaluation of Experiences Related to the Authority \\ Supervision of Inland Waterway Transportation \\ of Dangerous Goods Following the Change \\ of the Legal Framework
}

A katasztrófavédelmi rendszer átalakitása után 2012-töl a veszélyesáru-szállitás ellenőrzése nagyobb hangsúlyt kapott. Az eszközrendszer fejlesztése és az ellenörzéseket végrehajtó állomány tapasztalatszerzése növelte az ellenőrzések hatékonyságát és szakszerüségét. 2016-ban a szabálytalanságok szankcionálására hatályban lévő jogszabályt módositották. A módositás után a kiszabható bírságtételek jelentősen változtak. Jelen cikk célja a jogszabályváltozás hatásának vizsgálata, az eddigi tapasztalatok értékelése és az eredmények bemutatása.

Kulcsszavak: katasztrófavédelem, iparbiztonság, belvízi veszélyesáru-szállitás, bírság

Since 2012, after the reformation of the disaster management system, the control of the dangerous goods transportation came more into focus. Due to the development of the equipment system and the control personnel, experiences increased the efficiency and professionalism of the inspections. In 2016, the legal regulation in force dealing with the sanctioning of irregularities has changed. Consequently, the applied authority fines also changed significantly. The aim of this article is to review the effects of modified legal regulations, furthermore, to evaluate the experiences so far gained and to introduce the results.

Fővárosi Katasztrófavédelmi Igazgatóság Dél-budai Katasztrófavédelmi Kirendeltség, iparbiztonsági felügyelő, e-mail: robert.balogh@katved.gov.hu, ORCID: https://orcid.org/0000-0002-4318-7210 
Keywords: disaster management, industrial safety, inland waterway transport of dangerous goods, sanctioning

\section{Bevezetés}

Magyarország földrajzi helyzete miatt a környező országok közötti szállítások fontos útvonala, ezért a belföldi szállítások mellett jelentős a külföldi szállítmányok aránya is. Az ország közútjain, a vasúthálózatán és vízi úton leginkább a Duna folyón is jelentős mennyiségű veszélyes áru szállítása történik. Az utóbbi években az áruszállítás nagysága nőtt és a veszélyes áruk szállításának száma is növekedett.

Jogos társadalmi igényként, elvárásként jelentkezett, hogy a veszélyesáru-szállítások megnövekedett száma ellenére a közlekedés biztonsága ne romoljon, illetve a környezet terhelése ne fokozódjon. Ennek megfelelően a veszélyesáru-szállítmányok és a szállításokhoz kapcsolódó telephelyek rendszeres és következetes ellenőrzése, a balesetek kivizsgálása, valamint a hiányosságok és mulasztások szankcionálása az ellenőrző hatóságok fő megelőzési feladatává vált.

A második katasztrófavédelmi törvény hatálybalépését követően a közlekedési alágazati törvények (1995. évi XCVII. törvény a légiközlekedésről; 2000. évi XLII. törvény a víziközlekedésről; 2005. évi CLXXXIII. törvény a vasúti közlekedésről) módosításával megteremtette a jogi szabályozási hátterét annak, hogy a katasztrófavédelem önálló hatósági jogkörben végezheti a veszélyes áruk vasúti, vízi és légi szállításának ellenőrzését is, valamint ehhez kapcsolódóan a szabálytalanságok bírságolását és a balesetek kivizsgálását. A közlekedési alágazati törvények végrehajtási rendelete a veszélyes áruk vasúti és belvízi szállításának ellenőrzésére és a bírság kivetésére vonatkozó egységes eljárás szabályairól, továbbá az egyes szabálytalanságokért kiszabható bírságok összegéről, valamint a bírságolással összefüggő hatósági feladatok általános szabályairól szóló 312/2011. (XII. 23.) Korm. rendelet. ${ }^{3}$

A szankcionálás szabályaival kapcsolatosan 2016. november 29. napján módosították a vasúti és a belvízi veszélyesáru-szállítás hatósági felügyeletét szabályozó 312/2011. (XII. 23.) Korm. rendeletet. A módosítások a bírságtételek csökkentésével és bizonyos feltételek esetén a veszélyeztetés mértékén alapuló további $90 \%$-os és 70\%-os, illetve 50\%-os csökkentéssel érvényesült az arányosabb szankcionálás lehetősége. Több bírságtétel esetében a felelősségi körök változtatása is megtörtént a gyakorlati tapasztalatok alapján. A módosítások a nevesített bírságtételek darabszámának növelésével és részletesebb meghatározásokkal segítették az objektívebb szankcionálást. Az új szankciórendszert a 2017. január 13-a után, a jogszabály hatálybalépését követően indult eljárásokban kellett alkalmazni. ${ }^{4}$

Jelen cikkben a bírságrendelet kihirdetését és a módosítását követően a belvízi veszélyesáru-szállítás hatósági felügyeletével kapcsolatos tapasztalatokat elemzem. A cikkben található ábrák és táblázat elkészítéséhez a szükséges nyilvános minősítésü adatokat a BM Országos

KÁTAI-URBÁN - KOZMA - VASS 2015a.

KÁTAI-URBÁN - VASS 2019.

BALOGH-KOZMA-VASS 2019. 
Katasztrófavédelmi Főigazgatóság Országos Iparbiztonsági Főfelügyelősége biztosította. Az adatok a BM Országos Katasztrófavédelmi Főigazgatóságtól kikérhetők és bárki számára hozzáférhetők.

\section{A belvízi veszélyesáru-szállítás felügyelete}

A veszélyes áruk szárazföldi szállításának szabályait nemzetközi egyezmények határozzák meg, amelyeknek alapját képezi a veszélyes áruk szárazföldi szállításáról szóló irányelv. Ez az Európai Parlament és a Tanács 2008/68/EK irányelve (2008. szeptember 24.), amely a veszélyes áruk szárazföldi szállítását szabályozza, valamint az Európai Unió területén belül történő közúti, vasúti és belvízi szállítás szabályait is magában foglalja. ${ }^{5}$

Magyarországon a belvízi veszélyesáru-szállítást a The European Agreement concerning the International Carriage of Dangerous Goods by Inland Waterways (a továbbiakban: ADN), a 2000. május 26-án Genfben megkötött, módosított, a veszélyes áruk nemzetközi belvízi szállításáról szóló európai megállapodás szabályozza.

Az ADN-t Magyarországon a 177/2017. (VII. 5.) Korm. rendelettel hirdették ki, amely a Veszélyes Áruk Nemzetközi Belvízi Szállításáról szóló Európai Megállapodáshoz (ADN) csatolt Szabályzat kihirdetéséről, valamint a belföldi alkalmazásának egyes kérdéseiről szól. Az ADN-hez csatolt Szabályzat belföldi alkalmazásáról szóló 26/2017. (VII. 5.) NFM rendelet kiegészítéseket tartalmaz az ADN Szabályzat belföldi alkalmazásához. ${ }^{6}$

A belvízi veszélyes áruk szállításának ellenőrzési területeit és szállítással kapcsolatos szabályok megsértése esetén a szankciók rendszerét a 312/2011. (XII. 23.) Korm. rendelet határozza meg. A hatósági felügyelet, az ADN szabályainak ellenőrzése az egységes katasztrófavédelmi szervezet létrehozása után, 2012. január 1-jétől kezdődően a katasztrófavédelemi hatóság feladata.

A 2013. június 4-én hatályba lépett hatásköri jogszabályi változások következtében, a korábban kizárólag a területi szervek által végzett ellenőrzéseket a helyi szervek hajtják végre, növelve ezzel az ellenőrzések számát, illetve szolgálva a veszélyesáru-szállítás kapcsán bekövetkező balesetek hatékonyabb megelőzését. Az ellenőrzések végrehajtásában esetenként részt vesznek a katasztrófavédelmi megbízottak is. A 2013. év során a felülvizsgálati eljárások lefolytatását másodfokon a BM OKF központi szervtöl a területi szervek vették át. ${ }^{7}$

Jelenleg a BM Országos Katasztrófavédelmi Főigazgatóság a katasztrófavédelmi hatósági eljárás, illetve döntés tekintetében általános felügyeleti szervként jogosult eljárni.

\footnotetext{
2008/68/EK európai parlamenti és tanácsi irányelv.

177/2017. (VII. 5.) Korm. rendelet; 26/2017. (VII. 5.) NFM rendelet.

KÁTAI-URBÁN - KOZMA - VASS 2015b.
} 


\section{A belvízi veszélyesáru-szállítás ellenőrzésének tapasztalatai}

Magyarországon a veszélyes áru vízi szállításának katasztrófavédelmi hatósági ellenőrzésében a hajózhatósági adatok alapján (például meder, vízállás, hajóforgalom) csak a Duna menti megyék érintettek. Ezáltal az ellenőrzések Győr-Moson-Sopron, Komárom-Esztergom, Pest, Fejér, Bács-Kiskun, Tolna és Baranya megye, valamint a föváros hatáskörébe tartoznak. Ezek közül is kiemelt jelentőségü a vízi ellenőrzés Baranya megyében, valamint a fővárosban. Baranya megyében Mohácson található a szerb-horvát-magyar hármashatár, ahol kivétel nélkül minden belépő és kilépő vízi jármű átfogó ellenőrzésen megy át, hiszen itt kezdődik és ér véget a schengeni övezet. A föváros pedig a település katasztrófavédelmi besorolása, valamint speciális központi szerepe miatt számít kiemelt fontosságú területnek. Ennek oka - a teljesség igénye nélkül -, hogy jelentősen koncentráltan vannak jelen a fontos és védett közintézmények (például minisztériumok, hivatalok, a Parlament), Seveso hatálya alá tartozó felső küszöbértékű üzemek, védett személyek lakó- és közintézményei, a nemzetközi vízi forgalom lebonyolításában részt vevő üzemek, illetve a lakosság igen magas száma. ${ }^{8}$

A belvízi szállítások hatékonyabb ellenőrzése érdekében 2012-ben a Baranya Megyei Katasztrófavédelmi Igazgatóság Mohácsi Kirendeltsége állományából állandó hajóellenőri szolgálat alakult, amelynek tagjai 24/48 órás szolgálati rendben, a Mohács nemzetközi vízi határátkelőhely épületéből indulva folyamatosan ellenőrzik a veszélyes árut szállító hajókat. ${ }^{9}$

A Fővárosi Katasztrófavédelmi Igazgatóság a belvízi veszélyesáru-szállítások ellenőrzését a Szent Flórián tűzoltó hajó segítségével végzi, valamint a fővárosi veszélyes üzemekbe érkező szállítmányok esetében az üzemek kikötőiben, a szárazföldről is végrehajtják az ADN hatálya alá tartozó hajók ellenőrzését.

Az ellenőrzések végrehajtását a BM Országos Katasztrófavédelmi Főigazgatóság belső szabályozójában rögzített eljárási rend és egyéb hatósági eszközök (ellenőrzési kézikönyv és ellenőrzési jegyzőkönyvek az ADN-es tartály-, illetve szárazáru-szállító hajókhoz) segítik.

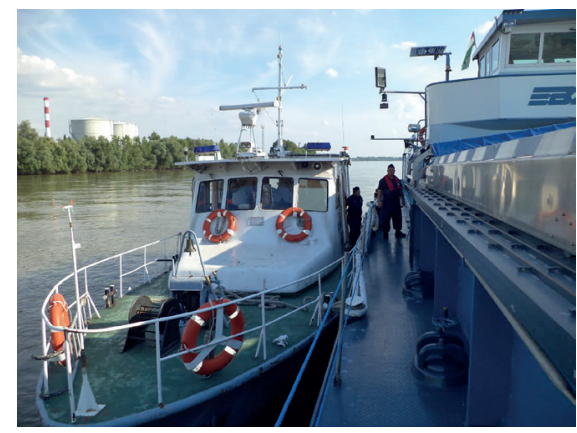

1. ábra. Belvízi veszélyesáru-szállítás ellenőrzése hajóról

Forrás: a szerző felvétele

KÁTAI-URBÁN - KISS 2014a.

KÁTAI-URBÁN - KOZMA - VASS 2015 b. 
Az 1. ábrán a 2013. július 10-én a Duna fővárosi szakaszán társhatóságokkal végrehajtott, menetben lévő veszélyes árut szállító hajó ellenőrzése látható.

A belvízi veszélyesáru-szállítás ellenőrzése nem csak a szállítók által előre bejelentett, vagy az online hajókövető RIS-rendszerben rögzített veszélyesáru-szállítmányok esetében történik. Az ellenőrzések során a bejelentési kötelezettséget elmulasztó, a rejtett és az illegális veszélyes szállítmányok felderítése is cél. Ezért azok a vízi szállítmányok is vizsgálat alá kerülnek, amelyek esetében az előzetesen rendelkezésre álló információk alapján feltételezhető, hogy nem veszélyes áru szállítása történik.

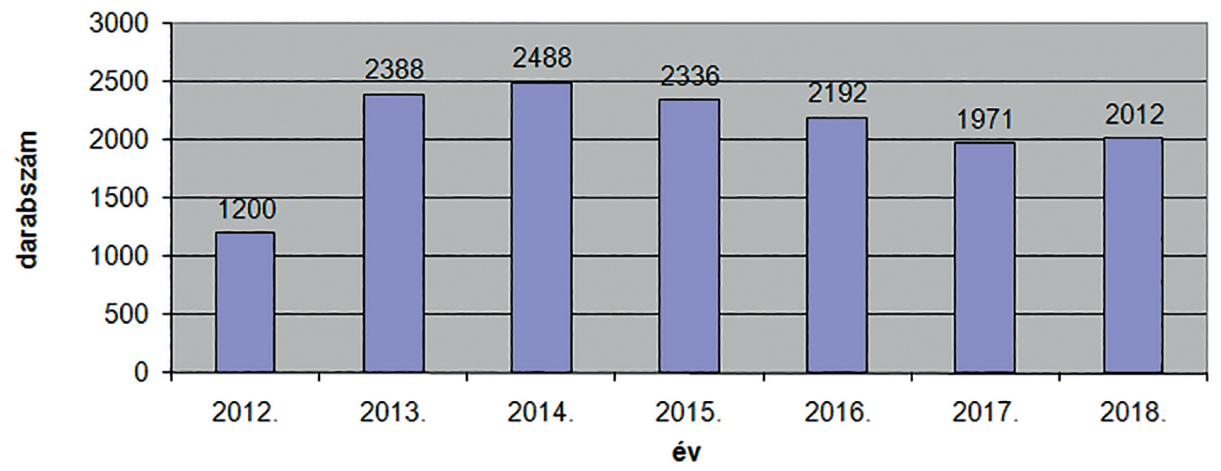

2. ábra. Az ellenőrzött vízi járművek száma 2012-2018. között

Forrás: a szerző szerkesztése

A katasztrófavédelem az ADN szabályainak ellenőrzését 2012-ben kezdte meg. Az ellenőrzött vízi jármüvek száma 1200-2488 db között változott (2. ábra).

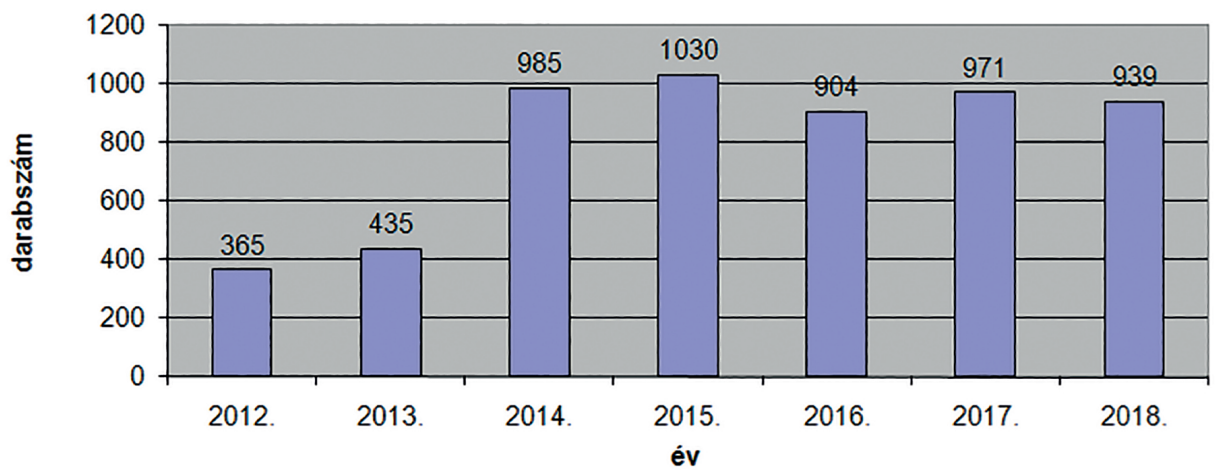

3. ábra. Az ellenőrzött veszélyes árut szállító vízi járművek száma 2012-2018. között

Forrás: a szerző szerkesztése 
A vizsgált időszakban az ellenőrzött veszélyes árut szállító, az ADN hatálya alá tartozó vízi jármüvek száma a 2012-es és a 2013-as év után jelentősen növekedett (3. ábra). A veszélyes árut szállító vízi járművek 2012. évi 365-ös darabszámról 2013-ban 435 db-ra nőtt. Az ellenőrzött ADN-es vízi járművek száma 2014-ben 985 db-ra emelkedett. Ez a változás a 2013. június 4-én hatályba lépett hatásköri jogszabályi változások miatt következett be. A korábban kizárólag a katasztrófavédelem területi szervei által végzett ellenőrzéseket 2014-ben már a helyi szervek nagyobb létszámú ellenőri állománya is végezte. Az ellenőrzött ADN-es vízi járművek száma 2014. évtől 2018-ig a 904 db/év és 1030 db/év között változott.

A 4. ábrán 2019. december 13-án Budapesten, a csepeli szabadkikötőben végrehajtott, veszélyes árut szállító hajó ellenőrzése látható.

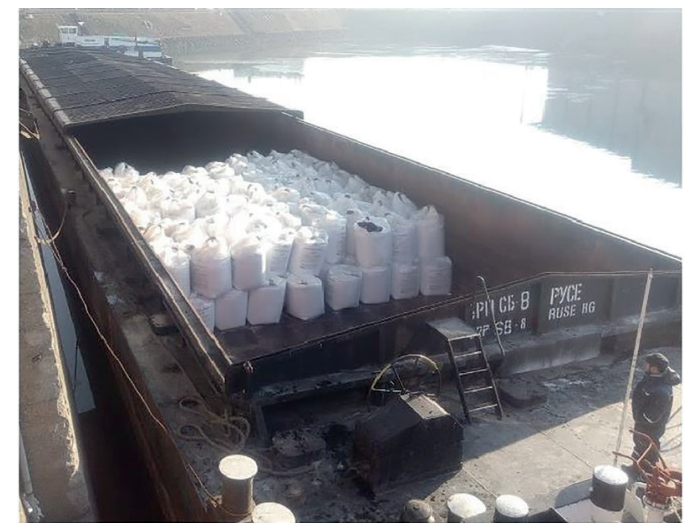

4. ábra. Belvízi veszélyesáru-szállítás ellenőrzése a szárazföldről

Forrás: a szerző felvétele

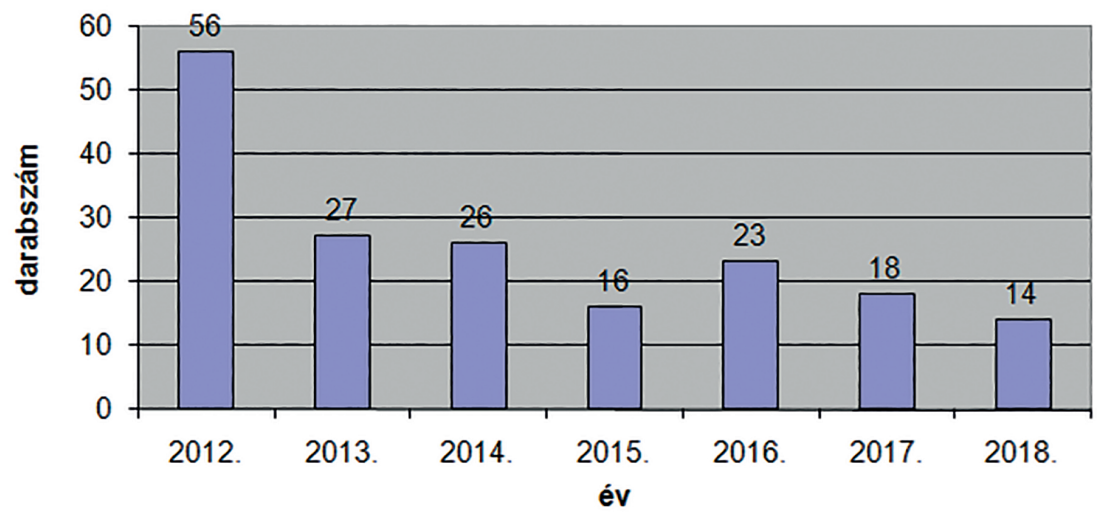

5. ábra. A belvízi veszélyesáru-szállítás szabályainak nem megfelelő - hibás - veszélyes árut szállító vízi járművek száma 2012-2018. között

Forrás: a szerző szerkesztése 
A belvízi veszélyesáru-szállítás szabályainak nem megfelelő - hibás - veszélyes árut szállító vízi járművek száma a katasztrófavédelem által végzett ellenőrzések 2012. évi kezdetén érte el a legmagasabb számot, összesen 56 db vízi jármü nem felelt meg az ADN előírásainak (5. ábra).

A 2012-es év során a legtöbb esetben az alábbi hiányosságokat állapították meg:

- az ADN-szabályzat teljes hiánya,

- az ADN-szabályzat nyelvezete nem megfelelö,

- az ADN-szabályzat nem a legfrissebb példányú,

- írásbeli utasítás teljes hiánya,

- írásbeli utasítás nyelvezete nem megfelelő,

- mérési eredményeket rögzítő napló hiánya,

- vészhelyzeti lékesedési riadóterv hiánya,

- gyúlékonygáz-detektor bizonyítvány és használati utasítás hiánya,

- az úszó létesítmény villamos berendezéseinek ellenőrzési bizonyítványának hiánya,

- a hajó tűzoltó készülékei és tüzoltótömlői ellenőrzési bizonyítványának hiánya,

- a fuvarokmányban a veszélyes árura vonatkozó megnevezést nem az ADN-nek megfelelően töltötték ki,

- a hajón nem volt fellelhető az előirt mennyiségü kézi tűzoltó készülék,

- a hajó tűzoltó berendezésein nem volt megtalálható a felülvizsgálati tanúsítvány,

- egyéni védőfelszerelés hiánya,

- különleges védőfelszerelés hiánya. ${ }^{10}$

A hibás ADN-es vízi jármüvek száma a következő években 14 db/év és 27 db/év között alakult annak ellenére, hogy az ellenőrzött veszélyes árut szállító hajók száma 2014-től jelentősen nőtt a 2012-es és a 2013-as évhez képest.

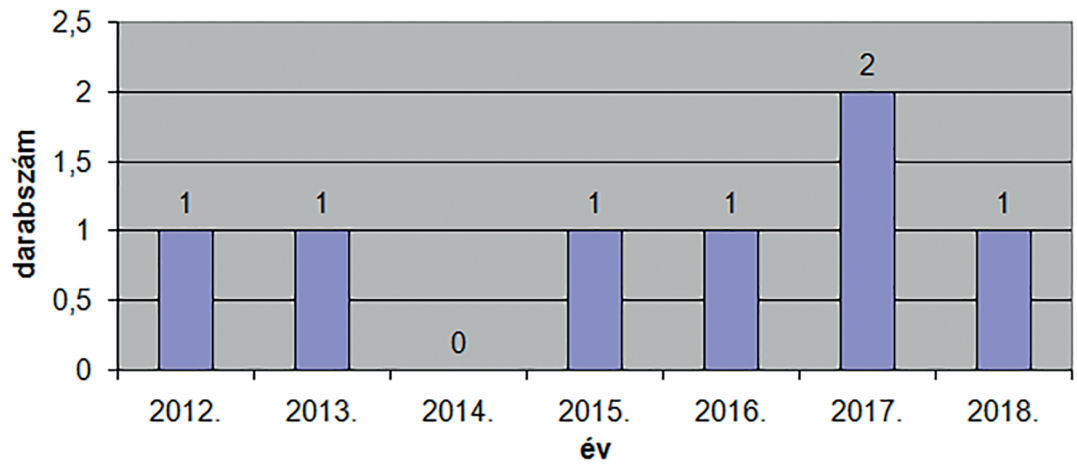

6. ábra. A belvízi veszélyesáru-szállítással kapcsolatos események, balesetek száma 2012-2018. között

Forrás: a szerző szerkesztése

10 KÁTAI-URBÁN - KISS 2014b. 
A vizsgált időszakban megfigyelhető, hogy a katasztrófavédelem által 2012-ben megkezdett belvízi veszélyesáru-szállítás ellenőrzések során a 2012. évben az 56 db feltárt szabálytalan szállítás magas száma ellenére csak egy esetben történt baleset. Az előzőekben bemutatottak szerint a 2014-es évtől az ellenőrzések száma és az ellenőrzött ADN-es vízi járművek száma jelentősen növekedett, azonban a szabálytalan szállítások száma csökkent és az események, balesetek száma éves szinten egy db volt, illetve 2014-ben egy db sem, míg 2017-ben két db következett be (6. ábra).

A 2012 óta növekvő ellenőrzési számok, az ellenőrzéseket végrehajtó állomány szakmai színvonalának fejlődése, a belvízi veszélyesáru-szállításban részt vevők szabálykövető magatartása ellenére is következhetnek be olyan események, amelyek veszélyeztetik a biztonságot, az emberi életet és egészséget, illetve a környezetet. A veszélyesáru-szállítással összefüggő események, balesetek számának alakulását sajnos nem csak az ellenőrzések mennyisége és minősége befolyásolja. Olyan külső körülmények is okozhatnak egy-egy eseményt, amely a jogszabálykövető magatartás esetén is bekövetkezhet.

\section{A belvízi veszélyesáru-szállítás hatósági eljárásainak tapasztalatai}

A hivatásos katasztrófavédelmi szerv eljárásai során a veszélyes áruk vasúti és belvízi szállításának ellenőrzésére és a bírság kivetésére vonatkozó egységes eljárás szabályairól, továbbá az egyes szabálytalanságokért kiszabható bírságok összegéről, valamint a bírságolással összefüggő hatósági feladatok általános szabályairól szóló 312/2011. (XII. 23.) Korm. rendelet 2012-ben történt hatályba lépését követően a belvízi veszélyesáru-szállítás hatósági felügyeletét a katasztrófavédelemi szervek mellett a hajózási hatóság és a rendőrség vízirendészeti szerve is ellátta. A katasztrófavédelmi szervek által végzett hatósági tevékenység magasabb szintű biztonsági kultúrát követelt meg a belvízi veszélyesáru-szállításban részt vevőktől. A belvízi veszélyesáru-szállítások ellenőrzése és a hatósági eljárások magas szintű szakmai színvonalon tartása a katasztrófavédelmi szervek ellenőrzést végző állományának is komoly feladatot jelentett. A folyamatos képzés, a megszerzett tapasztalatok megosztása és a hatósági tevékenységet segítő belső kiadványok elkészítése segítette az állományt.

A veszélyesáru-szállítási szakterületen problémaként jelentkezett, hogy az egyes igazgatóságok között továbbra is jelentős eltérés mutatkozik a hiányosságok feltárásában, az ellenőrzések hatékonyságában. Az igazgatóságok statisztikáit tekintve a felderítés adatai még mindig nagy szórást mutatnak, így nagyobb hangsúlyt kell fektetni a hiányosságok feltárására. Kiemelten fontos a szabálytalanság tényének és a szabálytalanságért felelős személynek egyértelmű meghatározása (bizonyítása). Az elsőfokú határozatokban fokozottabb figyelmet kell fordítani a kiszabott bírságok részletesebb indokolására, a felelősség kérdésének szélesebb körű vizsgálatára. ${ }^{11}$

A 312/2011. (XII. 23.) Korm. rendelet 2016-ban történt módosítását a 2012. óta megszerzett hatósági tapasztalatok és a társadalmi visszajelzések tették szükségessé. A módosítás fő célja az volt, hogy a katasztrófavédelmi szervek a bírságtételek kiszabásakor objektívebb módon

11 KÁTAI-URBÁN - KOZMA - VASS 2016 
tudják figyelembe venni a szállítók által elkövetett szabálytalanságok súlyát, illetve a bírságot megfizetők körét. A jogi szabályozás módosítása után a nevesített bírságtételek darabszámának növelése és a meghatározások pontosítása segítette a jogalkalmazás gyakorlatát. Az egyes szabálytalanságok könnyebben és egyértelmüen besorolhatóvá váltak. A társadalmi visszajelzések figyelembevételével a bírságtételek összege csökkent, és a szabálytalanság körülményeit mérlegelve, a veszélyeztetés mértékén alapuló további 90\%-os és 70\%-os, illetve $50 \%$-os csökkentés vált lehetővé.

Több bírságtétel esetében a felelősségi körök változtatása segítette az objektívebb szankcionálást. Jó példa erre többek között a veszélyes áru szivárgásával, a rakomány rögzítésével és a jármü, a tartály és a konténer jelölésével kapcsolatos hiányosságok módosítása. ${ }^{12}$

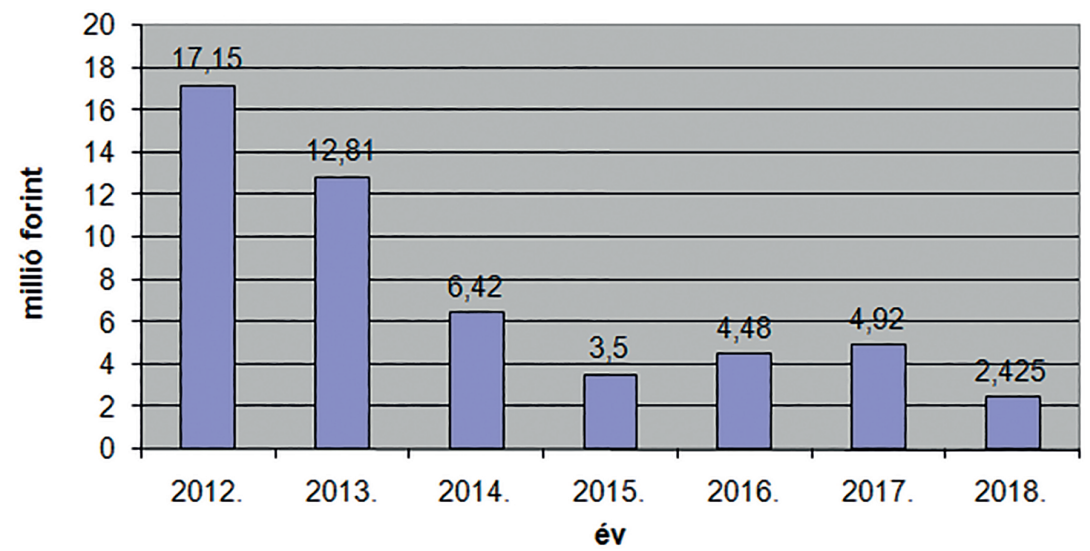

7. ábra. A kiszabott bírságok összege 2012-2018. között

Forrás: a szerző szerkesztése.

Az egy évben kiszabott bírságok összege 2012. és 2013. évben volt a legmagasabb 17,15 és 12,81 millió forint. 2012. évben 65 db, míg 2013. évben 27 db szabálytalan vízi jármü esetén indult eljárásban szabták ki ezeket a bírságösszegeket. 2014 és 2016 között a kiszabott bírságok összege jelentősen csökkent (6,42, 3,5 és 4,48 millió forint), azonban a szabálytalan vízi járművek száma a 2013-as év adataihoz képest nem csökkent ilyen arányban. A kiszabott bírságok összegének csökkenését a katasztrófavédelmi szervek által felderített hiányosságok kisebb súlya indokolta (7. ábra).

A bírságjogszabály változásának hatálybalépését követően a 2017. január 13-a után indult belvízi veszélyesáru-szállítással kapcsolatos katasztrófavédelmi hatósági eljárások esetében már a csökkentett bírságösszegekkel adták ki a bírsághatározatokat. A csökkentett bírságtételek mellett bizonyos esetekben a veszélyeztetés mértékét, a szállítás körülményeit figyelembe véve

12 BALOGH-KOZMA-VASS 2018. 
további $90 \%$-os és $70 \%$-os, illetve 50\%-os korrekció volt alkalmazható, amely lehetőséget adott a kiszabott bírságok összegének nagymértékű mérséklésére.

A 2017-2018-as évben a szabálytalan szállítások száma tovább csökkent, és a kiszabott bírságok összege 2018-ban volt a legkevesebb, 2,425 millió forint.

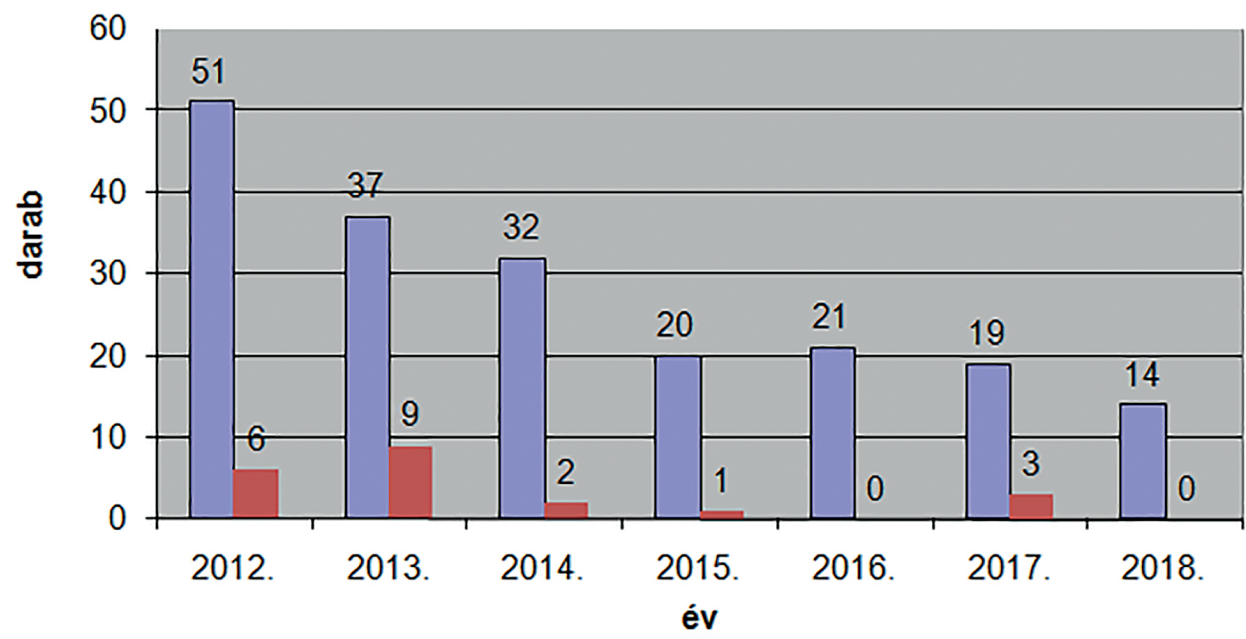

8. ábra. Az elsőfokú és a másodfokú bírsághatározatok száma 2012-2018 között. Kék szín jelöli az elsőfokú, barna szín a másodfokú határozatok számát

Forrás: a szerző szerkesztése

Az elsőfokú ügyek alakulásában megfigyelhető, hogy a 2012. évben kiemelkedő mennyiségü a kiadott határozatok száma a vizsgált időszakban, majd évről évre csökken ez a mennyiség. A másodfokú határozatok száma 2012-ben $6 \mathrm{db}$, 2013-ban $9 \mathrm{db}$, majd további csökkenés figyelhető meg, 2016-ban és 2018-ban pedig az elsőfokú döntések ellen fellebbezés nem érkezett, másodfokú eljárás nem volt. A másodfokú eljárások csökkenése azt mutatja, hogy az állomány folyamatos képzése és a megszerzett gyakorlata az ellenőrzések és a hatósági eljárások magasabb színvonalú és szakszerübb lefolytatását teszi lehetővé. A belvízi veszélyesáru-szállításban részt vevők részéről a 2017. január 13. napját követően indult eljárásokban alkalmazott, módosult szankciórendszer elfogadottságát mutatja a másodfokú hatósági eljárások alacsony száma (8. ábra).

A katasztrófavédelem 2012. január 1-jétöl 2018. december 31-ig végrehajtott belvízi veszélyesáru-szállítással kapcsolatos felügyeleti tevékenységének összefoglaló adatai az alábbi táblázatban láthatók. 
1. táblázat. A belvízi veszélyesáru-szállítás hatósági felügyeletének adatai 2012-2018. között

\begin{tabular}{|l|c|c|c|c|c|c|c|}
\hline $\begin{array}{l}\text { Belvízi veszélyesáruszálli- } \\
\text { tás-ellenörzések adatai }\end{array}$ & 2012 & 2013 & 2014 & 2015 & 2016 & 2017 & 2018 \\
\hline $\begin{array}{l}\text { Ellenörzési alkalmak száma } \\
\text { (db) }\end{array}$ & 315 & 498 & 725 & 643 & 634 & 599 & 630 \\
\hline $\begin{array}{l}\text { Ellenörzött vízi jármüvek } \\
\text { száma (db) }\end{array}$ & 1200 & 2388 & 2488 & 2336 & 2192 & 1971 & 2012 \\
\hline $\begin{array}{l}\text { Ellenőrzött veszélyes árut } \\
\text { szállító (ADN-es) vízi jármü- } \\
\text { vek száma (db) }\end{array}$ & 365 & 435 & 985 & 1030 & 904 & 971 & 939 \\
\hline Hibás vízi jármüvek száma (db) & 56 & 27 & 26 & 16 & 23 & 18 & 14 \\
\hline Felderíśs aránya (\%) & 15,34 & 6,2 & 2,63 & 1,55 & 2,54 & 1,85 & 1,49 \\
\hline $\begin{array}{l}\text { Telephelyi ellenőrzések szá- } \\
\text { ma (db) }\end{array}$ & 5 & 14 & 28 & 22 & 26 & 21 & 22 \\
\hline $\begin{array}{l}\text { Elsőfokú hatósági határozatok } \\
\text { száma (db) }\end{array}$ & 51 & 37 & 32 & 20 & 21 & 19 & 14 \\
\hline $\begin{array}{l}\text { Másodfokú határozatok szá- } \\
\text { ma (db) }\end{array}$ & 6 & 9 & 2 & 1 & 0 & 3 & 0 \\
\hline Bírságok összege (millió forint) & 17,15 & 12,81 & 6,42 & 3,5 & 4,48 & 4,92 & 2,425 \\
\hline Bírósági eljárások száma (db) & 0 & 0 & 0 & 0 & 0 & 0 & 0 \\
\hline Balesetek száma (db) & 1 & 1 & 0 & 1 & 0 & 3 & 1 \\
\hline
\end{tabular}

Forrás: a szerző szerkesztése

\section{Összegzés}

A katasztrófavédelemről és a hozzá kapcsolódó egyes törvények módosításáról szóló 2011. évi CXXVIII. törvény hatálybalépését követően a víziközlekedésröl szóló 2000. évi XLII. törvény módosításával 2012. óta a katasztrófavédelem önálló hatósági jogkörben végezheti a veszélyes áruk vízi szállításának ellenőrzését, valamint ehhez kapcsolódóan a szabálytalanságok bírságolását és a balesetek kivizsgálását.

A belvízi veszélyes áruk szállításának ellenőrzési területeit és szállítással kapcsolatos szabályok megsértése esetén a szankciók rendszerét a hivatásos katasztrófavédelmi szerv eljárásai során a veszélyes áruk vasúti és belvízi szállításának ellenőrzésére és a bírság kivetésére vonatkozó egységes eljárás szabályairól, továbbá az egyes szabálytalanságokért kiszabható bírságok összegéről, valamint a bírságolással összefüggő hatósági feladatok általános szabályairól szóló 312/2011. (XII. 23.) Korm. rendelet határozza meg. A szankcionálás szabályaival kapcsolatosan 2016. november 29. napján módosították a kormányrendeletet. A módosítások a bírságtételek csökkentésével és bizonyos feltételek esetén a veszélyeztetés mértékén alapuló további $90 \%$-os és $70 \%$-os, illetve $50 \%$-os csökkentéssel érvényesült az arányosabb szankcionálás lehetősége. A gyakorlati tapasztalatok alapján több bírságtétel esetében a felelősségi körök változtatása is megtörtént. A módosítások a nevesített bírságtételek darabszámának növelésével és részletesebb meghatározásokkal segítették az objektívebb szankcionálást. Az új szankciórendszert 2017. január 13-a után, a jogszabályban történt változások hatálybalépését követően indult eljárásokban kellett alkalmazni. Ezek a változások a 2017. és 2018. évben a másodfokú hatósági eljárások számát is 
alapul véve a módosult szankciórendszer elfogadottságát mutatja azok körében, akik a veszélyes áruk belvízi szállításában vesznek részt.

A katasztrófavédelem hatékony és nagyszámú ellenőrzések végrehajtásával törekszik a belvízi veszélyesáru-szállítás szabályainak maradéktalan betartására késztetni a szállításban részt vevőket. A katasztrófavédelmi szervek hatósági ellenőrzési számait vizsgálva megállapítható, hogy az ellenörzött vízi jármüvek száma 2012 óta folyamatosan magas, a szabálytalan szállítások száma pedig évről-évre csökken. A 2012. évben megkezdett belvízi veszélyesáruszállítás-ellenörzések során a 2012. évben az 56 db feltárt szabálytalan szállítás magas száma ellenére csak egy esetben történt baleset. A 2014-es évtől az ellenőrzések száma és az ellenőrzött ADN-es vízi járművek száma jelentősen növekedett, azonban a szabálytalan szállítások száma csökkent és az események, balesetek száma éves szinten egy db volt, illetve 2014-ben egy db sem, míg 2017-ben két db következett be. Megállapítható, hogy a szállításban részt vevők szabálykövető magatartása ellenére is következhetnek be olyan események, amelyek veszélyeztetik a biztonságot, az emberi életet és egészséget, illetve a környezetet. A veszélyesáru-szállítással összefüggő események, balesetek számának alakulását sajnos nem csak az ellenőrzések mennyisége és minősége befolyásolja.

\section{Felhasznált irodalom}

BALOGH Róbert - KozMA Sándor - VASS Gyula (2018): A közúti veszélyes áru szállítás hatósági felügyeletével kapcsolatos tapasztalatok értékelése a bírság jogszabály változásának következtében. Védelem Tudomány, 3. évf. 3. sz. 100-111. Elérhető: www.vedelemtudomany.hu/articles/07-balogh-kozma-vass.pdf (A letöltés dátuma: 2019. 11. 16.)

BALOGH Róbert - KOZMA Sándor - VASS Gyula (2019): A vasúti veszélyesáru-szállítás hatósági felügyeletével kapcsolatos tapasztalatok értékelése a bírságjogszabály változásának következtében. Müszaki Katonai Közlöny, 29. évf. 3. sz. 21-34. DOI: https://doi.org/10.32562/mkk.2019.3.2

KÁTAI-URBÁN Lajos - KIss Enikő (2014a): A veszélyes áru belvízi szállításával kapcsolatos katasztrófavédelmi feladatok végrehajtási tapasztalatainak értékelése. Hadmérnök, 9. évf. 1. sz. 81-87. Elérhető: http://hadmernok.hu/141_07_katail.pdf (A letöltés dátuma: 2019. 11. 12.)

KÁTAI-URBÁN Lajos - KISS Enikő (2014b): A Mohácsi Iparbiztonsági Hatóság veszélyesáru-szállítási vízi ellenőrzési tapasztalatainak értékelése. Bólyai Szemle, 23. évf. 1. sz. 98-108. Elérhető: https://folyoiratok.uni-nke.hu/document/uni-nke-hu/bolyai-szemle-2014_-ev-1_-szam.original.pdf (A letöltés dátuma: 2019. 11. 12.)

KÁTAI-URBÁN Lajos - KozMA Sándor - VASS Gyula (2015a): Veszélyes szállítmányok felügyeletével kapcsolatos jog- és intézményfejlesztési tapasztalatok értékelése. Hadmérnök, 10. évf. 3. sz. 92108. Elérhető: www.hadmernok.hu/153_08_katayul_ks_vgy.pdf (A letöltés dátuma: 2019. 11. 12.)

KÁTAI-URBÁN Lajos - KozMA Sándor - VASS Gyula (2015b): Veszélyes szállítmányok felügyeletével kapcsolatos hatósági tapasztalatok értékelése. Hadmérnök, 10. évf. 4. sz. 101-114. Elérhető: www. hadmernok.hu/154_10_kataiul_ks_vgy.pdf (A letöltés dátuma: 2019. 11. 12.)

KÁTAI-URBÁN Lajos - KOZMA Sándor - VASS Gyula (2016): Veszélyes szállítmányok felügyeletének fejlődése Magyarországon. Védelem Tudomány, 1-41. Elérhető: http://vedelem.hu/letoltes/ anyagok/-veszelyes-szallitmanyok-felugyeletenek-fejlodese-magyarorszagon.pdf (A letöltés dátuma: 2019. 11. 16.)

KÁTAI-URBÁN Lajos - VASS Gyula (2019): Veszélyes üzemek és szállítmányok biztonsága Magyarországon. Védelem Tudomány, 4. évf. Iparbiztonság különszám. 45-82. Elérhetö: http://vedelemtudomany. hu/articles/03-katai-vass.pdf (A letöltés dátuma: 2019. 11. 12.) 


\section{Jogi források}

2000. évi XLII. törvény a víziközlekedésről

2011. évi CXXVIII. törvény a katasztrófavédelemről és a hozzá kapcsolódó egyes törvények módosításáról Az Európai Parlament és a Tanács 2008/68/EK irányelve (2008. szeptember 24.) a veszélyes áruk szárazföldi szállításáról (EGT-vonatkozású szöveg)

312/2011. (XII. 23.) Korm. rendelet a hivatásos katasztrófavédelmi szerv eljárásai során a veszélyes áruk vasúti és belvízi szállításának ellenőrzésére és a bírság kivetésére vonatkozó egységes eljárás szabályairól, továbbá az egyes szabálytalanságokért kiszabható bírságok összegéről, valamint a bírságolással összefüggő hatósági feladatok általános szabályairól

177/2017. (VII. 5.) Korm. rendelet a Veszélyes Áruk Nemzetközi Belvízi Szállításáról szóló Európai Megállapodáshoz (ADN) csatolt Szabályzat kihirdetéséröl, valamint a belföldi alkalmazásának egyes kérdéseiröl

26/2017. (VII. 5.) NFM rendelet a Veszélyes Áruk Nemzetközi Belvízi Szállításáról szóló Európai Megállapodáshoz (ADN) csatolt Szabályzat belföldi alkalmazásáról 